\title{
Producing Creative Generation through Nation Character Education
}

\author{
Hambali \\ Faculty of Education University of Riau, Indonesia
}

\section{Doi:10.5901/jesr.2015.v5n3p81}

\begin{abstract}
This study was conducted to get students' perspective on their acceptance and the implementation of creative nation education at the lower secondary schools. The perspective focused on students' acceptance of the nation characters inculcated by teachers in the classrooms, school environment and co-curricular activities. Samples of the study were 836 students from 22 secondary schools in Pekanbaru, Riau, Indonesia. A pilot study was conducted and the alpha cronbach was analysed. All constructs were at the high reliability level which was between 0.774 to 0.931 . Data was analysed descriptively to get the mean and percentage. Inferential analysis involving Pearson Correlation and SEM were also conducted using SPSS 22.0 and AMOS 18.0. This study has found students' acceptance towards nation character and its implementation of creative characters was at the satisfactory or modest level. Results also showed that students' acceptance on Nation Character Education in the classrooms, school environment and during co-curricular activities has significant contribution towards the implementation of creative character education. The implication of this study shows that the implementation would be more successful if there are more parties involve in providing various efforts to strengthen creative nation characters among students. The findings have shown the importance of implementing nation character education across the curriculum, organising school programs and providing various co-curricular activities for the purpose of establishing holistic education.
\end{abstract}

Keywords: acceptance of nation character, implementation of creative nation character, students, classrooms, school environment and co-curriculum.

\section{Introduction}

Modernisation and information based globalisation threats have rapidly changed people's way of thinking and gradually new moral values, culture and characters are created in the society. There have been various discussions regarding the impacts of globalisation on socio-culture and the emergence of new trends in the society. Hence, according to the Indonesian Minister of Education and Culture (Sudrajat, A. 2011), character education is extremely needed because education is not only to produce people who have intelligent mind, but also to shape good attitudes and moral values to strengthen individual personality.

Currently, teenagers are influenced by various negative cultures especially hedonism due to uncontrollable information and internet access. They no longer spend their time to improve their thinking nor to improve their social competency (Widodo, Tri and Sri Kadarwati. 2013). This matter is the major consent of the society, hence, schools are the best platform to retract the situation by providing formal lessons of character education to develop positive characters of the young generation. School environment would provide better opportunities to inculcate nation character education during formal teaching and learning sessions in the classroom, during school programs and also during co-curricular activities. According to Ajat Sudrajat and Ari Wibowo (2013), these three environments are the important platforms to introduce positive values and to develop positive characters in students' personality. The values would become a strong shield against globalisation threats and challenges.

Indonesia has a very unique identity as it is actually a united nation of various ethnicities (Tilaar, 2007). Due to that, a united national character is developed to reflect the nation. According to Williams (2000), nation character is the basic behaviours established strongly as an identity of a country or a nation. The identity is referred to as a universal value of interaction behaviours among the people. Generally, character is a universal and comprehensive value of life, pillared by peace, respect, cooperation, freedom, happiness, honesty, humility, love, responsibility, simplicity, tolerance, and unity. Those values are practised by the people of Indonesia but they still need to be studied and upgraded. This is because the Indonesian characters are not yet compatible with the values practised by people of other nations of the world.

Characters are needed in the social environment. Attitudes and moral are developed through social interaction with other people. Ibn Khaldun (2002) stated that one who interacts in a good environment would have good attitudes 
and behaviours based on his observation on the environmental factors which have great influence on one's way of life. Booi-Chen Tan (2011) also agreed on the effects of environment on one's attitudes and values. It is also the last stage of social development process which developed by social learning of stimulations, feedbacks, reinforcement, obedience, identification, modeling and copying.

Soedarsono (2000) defined characters as a set of moral values and norms owned by the society, which work as guidelines in the dimension of thinking, attitudes, behaviors and actions. The values shape a solid personality of an individual by embedding one's personal values with values of his or her social environment. Character is also referred to the moral values which form one's pride and dignity. They are also the personal benchmark for one's good or bad characters. Those characters determine and reflect the nation's identity and cultural heritage which are treasured or preserved as the vital part of life.

According to Kilpatrick (1992), nation character development is a translation of process from knowing to habits. Knowledge acquired is then applied as actions through trainings, practice and continuous education to differentiate between good influences and bad influences. Doni Koesoema (2007) assumed character as a form of personality influenced by three learning environments; the house, the school and the society. One is considered of having good character when his behaviours are according to the religious and moral values. According to al-Na'imy (1994), people are different due to their surroundings. Those who are at a supportive environment, would have the tendency to become good people and vice versa. Gede Raka (2011), related the strength of a character with good psychological elements, so matured people are always thought to have consistent characters.

There are 18 values stated in the Nation Character Education Blue Print (2010). The values are described in details in the Nation Character Curriculum published by the Curriculum Centre of the National Education Department (PKDPN, 2010). The values are summed up as the following (1) Religious: obeying the religious rules in attitudes and behaviours (2) Honesty: Reliable in speech, action and work ethics (3) Tolerance: attitudes and behaviours that appreciate others of different religions, ethnics, opinions, attitudes and actions. (4) Discipline: adhere to the law and regulations (5) Hardworking: Behaviours and attitudes towards task fulfillment (6) Creative: Always think to produce something new. (7) Self-reliance: Independent in action and attitude, do not need others to complete tasks or problem. (8) Democratic: Fair to self and others (9) Curiosity: always have the urge to know details of something learnt, seen and heard.

The $10^{\text {th }}$ value of nation character is (10) patriotism: The way of thinking, action and vision are always putting the nation or country as the highest priority (11) Love for the country: The way of thinking, action and vision are always putting the nation or country as the best interest. (12) Appreciating performance: Attitudes and actions which encourage one to perform the best for his society, and at the same time admitting and respecting others' ability (13) Friendly/Communicative: Attitudes and actions which are always respecting others and comfortable with other people. (14) Peace lover: attitudes and actions which encourage one to accomplish something useful for the society and always respect others. (14) Reading habit: Taking reading as a hobby and an avid reader to any reading materials to enrich his own knowledge. (16) Care for the environment: Attitudes and actions which always try to prevent any destruction of the environment (17) Social awareness: Having kind and helpful attitudes towards others and society in need. (18) Responsible: Always ready to perform the best and shoulder responsibility perfectly for oneself, society, the environment (for the Mother Nature, social and culture), the country and the AL-Mighty.

\subsection{Nation Character}

Character is referred to one's habit, attitude and personality. According to Lickona (1996), character begins with one's knowledge about moral (moral knowing), having the urge to execute the good values (moral feeling) and taking action to develop good behaviour (moral behaviour). Character is also referred to a set of knowledge (cognitive), attitudes, motivations, behaviours and personality (skills). The Learning Methodology of teacher training has provided a manual to inculcate cultural values to develop competitiveness and nation character. The same guidelines were also published by The Curriculum Development Centre, Ministry of Education for the Republic of Indonesia (2010). The publication and manual have described nation character education as to develop character, habits, attitudes or personalities based on the Indonesian cultural values. This study focused on four components of character values which stemmed from the cultural values. The four components are (1) religious and spiritual values to develop religious characters; (2) patriotism and citizenship values to develop nationalist character; (3) values of social relation to develop productive character also (4) self-reliance and self-thinking to develop creative characters. 


\subsection{Creative characters}

Weisberg (1999) defined creative character as something which involves one's thinking to create new ideas or to change something to look extraordinary. Apart from that, Gede Raka (2011) defined creative character as a form of behaviours which become the impetus to develop a community and a country in varios areas. Whereas, in the context of this study, creative characters are creativity values owned by individuals to perform something whether in learning or working creatively. The creative values allow one to diversify his actions, methods and approaches out of the box. The creativity comes from self-esteem, reading habit/culture, creative thinking and out of curiosity. Creative values are also based on how an individual solves a problem independently without troubling others. This attitude allows one to come out with something different in various aspects of his life and this indirectly becomes the most important thing to develop the character of the Indonesian people.

Creative character is more about the thinking aspect and open mindedness in order to have a good life by having self-confidence, adopting reading culture to enrich knowledge, having creative thinking to get new brilliant ideas and innovative, and also translating curiosity by asking questions, taking notes and attending academic events.

Creative characters are divided into four components of characters (1) self-esteem, (2) reading habit/culture, (3) creative thinking and (4) curiosity. The four values reflect the need of creativity by exploring new things independently. The characteristics are in line with the list of creative characters described by Conny Semiawan, dkk. (1984). A study by Ruyadi (2010) found that the implementation of character education would be more effective if it was implemented based on the local culture and background of the students. Due to that, the process of persevering cultural heritage for the purpose of developing nation character involves institutionalization, socialization, internalization and acculturation processes. In relation to that, Sumaatmadja (2002) admitted that there is a connection between education and acculturation in the process of developing nation character.

\subsection{Classrooms}

Classroom is the basic platform for educational process and human development in the school. This room is the main arena for teachers to creatively implement their skills, expertise and competencies to inculcate character values. Various strategies and pedagogical elements are needed to ensure the implementation has positive impacts on students' cognitive and affective skills. According to Biggs (1987) classroom learning and teaching would only be successful and effective when the teacher is able to use his competencies and expertise to lead, to teach, to interact and to execute affective elements in a fun learning condition of a classroom.

\subsection{The school culture}

School is a formal education institution which provides the best climate and conducive environment to develop young people by providing knowledge and opportunity to practise the knowledge. In school, students are conditioned to good habits and routines, hence their behaviours are cultured to form great personalities. Among the routines which are parts of the Indonesian school cultures are raising the national flag during formal assembly, greeting, and cooperative learning. It is a must for the Indonesian schools to organise various programs and integrated activities for the purpose of developing students' characters. Some of the programs are Anti-corruption program, Independence month, and Kartini Day. According to Character Education Partnership (2000), there are at least three types of cultures needed to be developed in schools, they are: (1) academic culture - taking initiative to ensure academic success by organising various programs and activities, (2) acculturation of culture - to promote moral values to strengthen students' personalities, and (3) democratic culture - training students to think, to voice out and to expand ideas for the purpose of increasing their self-confidence and shaping them to become good citizens.

According to Sumaatmadja (2002), school education transforms the socio-culture system. Well-trained teachers filter and promote the socio-culture to produce good citizens in line with the country's educational goals. The educational system is expected to develop students' potentials and self-esteem, hopefully they would become religious, healthy, knowledgeable, confident, creative, democratic and responsible people.

\subsection{Co-curriculum}

Co-curricular activities are referred to activities conducted for sports, games, clubs, academic societies and uniform 
bodies. Those activities are conducted out of the classrooms, however they are hidden education to develop students' characters through cooperation, team work, competitions and team spirit. These forms of education promote students' self-esteem and increase their level of self-confidence.

\subsection{Practising Nation Characters}

Characters are developed through an educational process by knowing the good, living the good and doing the good. The best indicator to signal a well-developed character is by looking at changes of students' behaviours from the cognitive aspect (knowing the good),(Sudrajat, 2011). Another indicators are the way students perform and practise (doing the good) the values that they have acquired in any situation (living the good). Nation character practice in this study is referred to how students of Pekanbaru secondary schools perform their religious characters, nationalist characters, creative characters and productive characters, due to the implementation of Nation Character Education in their schools.

This study analysed students' perspective on their acceptance on the implementation of Nation Character Education in the classrooms, school environment and during co-curricular activities. The main objective was to focus on creative characters. Hence, this study measured the level of creative characters as practised by students at the government or national schools.

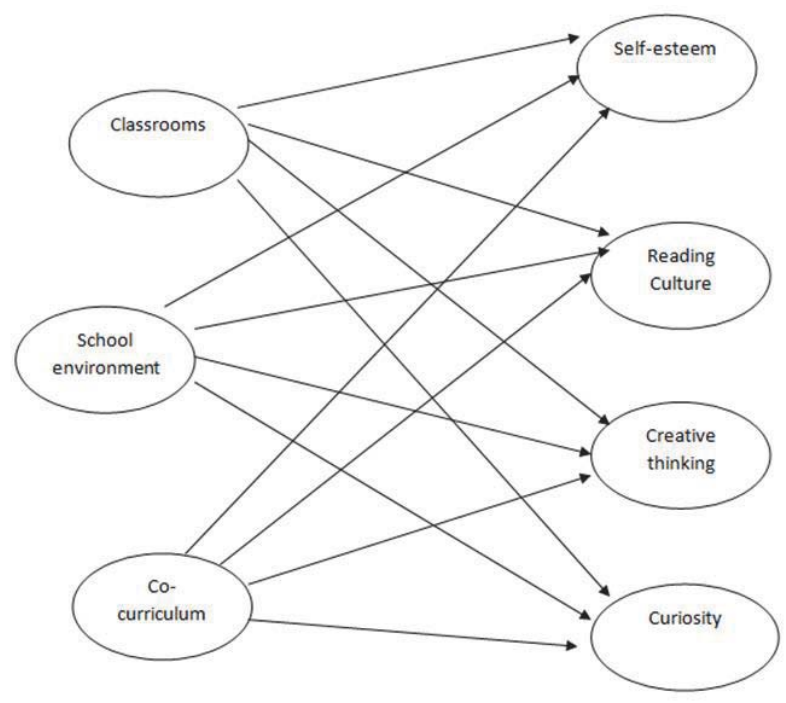

Figure 1. Research Conceptual Framework

The objectives of this research are:

1. To determine the level of students' acceptance on the implementation of Nation Character Education (NCE)

2. To determine how students' performed creative characters

3. To identify the relationship between the implementation of NCE with students' acceptance on how creative characters are implemented

4. To determine how students' acceptance of Nation Character Education contributes to the way they perform/practise creative characters.

\section{Methodology}

A survey was done involving 836 students from 22 lower secondary schools in Pekanbaru, Riau, Indonesia. Systematic random sampling was used to determine the samples, which were selected based on Taylor \& Bogdan (1984) and Seidman (1998) suggestions of the four criteria of research sampling. A questionnaire was designed to answer the research questions by referring to the characteristics of school culture. Items of the questionnaire were designed based 
on Nation Character theories developed by Lickona (1996), Kilpatrick (1992), and Character Development Blue Print (2010) and also adapted from a questionnaire developed by Ruyadi (2010). 30 students were involved in a pilot study to determine the reliability of the questionnaire. Results of the pilot study based on the alpha cronbach analysis found that all constructs were at a high reliability level between 0.774 to 0.931 . Both descriptive and inferential data analysis were used to get the mean, percentage, correlation and regression scores using SPSS 22.0 and the Amos 18 software.

\section{Findings}

\subsection{Students' acceptance on the implementation of Nation Character Education during teaching and learning process}

Descriptive analysis was done to get the mean and standard deviation to determine students' acceptance on the implementation of Nation Character Education. Detail of the analysis is described in Figure 2:

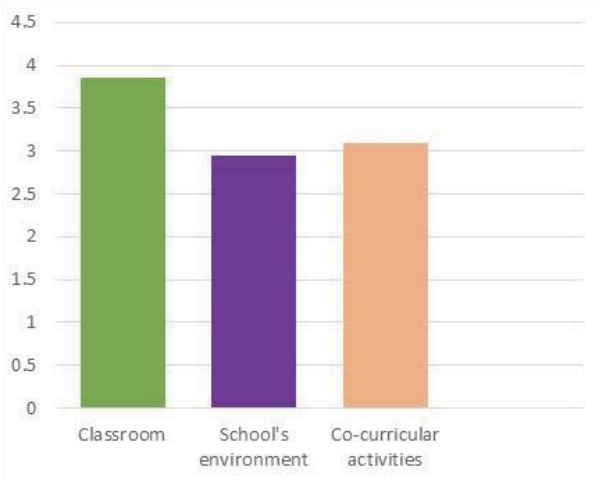

Figure 2. The level of Students' acceptance on the implementation of Nation Character Education

Figure 2 shows students' acceptance on the implementation of Nation Character Education in the class (mean=3.86), which is at a high level and recorded the highest mean. Whereas, students' acceptance of the implementation of NCE during co-curricular activities (mean $=3.09$ ) is at a satisfactory/modest level. The level of acceptance on the implementation at the school environment is also at the satisfactory level with the mean $=2.95$. In overall, it was found that students acceptance is at the satisfactory level (mean=3.30). The level of acceptance will be discussed in detail.

\subsection{Creative Characters as practised by students}

Descriptive analysis based on the mean score was conducted to determine the level of creative characters practised by students. Creative characters were divided into four aspects: self-esteem, reading habit/culture, creative thinking and curiosity. The finding is shown in the following Figure 3:

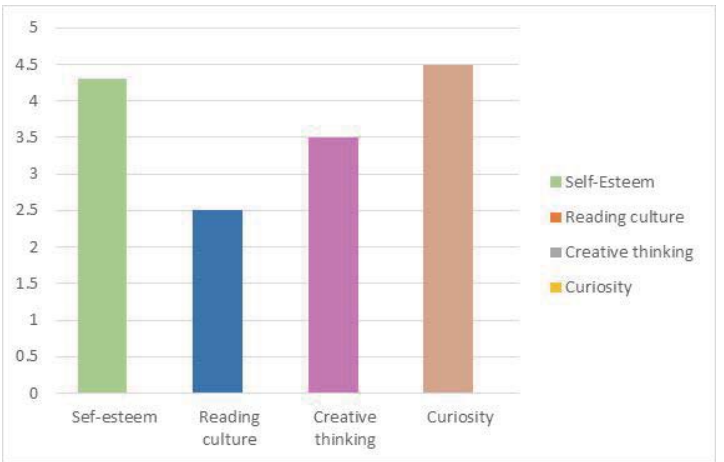

Figure 3. Creative Characters as practised by students 
Figure 3 shows the level of how students' practised creative characters. The aspect which has the highest mean is selfesteem (mean $=3.66$ ) and relatively it shows a high level of practice. This is followed by curiosity (mean $=3.66)$ which also indicates a high level of practice. Whereas, the aspect of creative thinking (mean=2.94) indicates a satisfactory or modest level of practice. The overall result shows that students' practise of creative characters is at a modest level $($ mean $=3.33$ ).

\subsection{The relationship between the implementation of NCE with students' acceptance on the implementation of creative} characters

Pearson correlation analysis was conducted to determine the relationship between students' acceptance of NCE with the implementation of creative characters, and the result is shown in Table 1 below:

Table 1. The relationship between students' acceptance of NCE with the implementation of creative characters

\begin{tabular}{lccc}
\hline \multirow{2}{*}{ Relationship/environment } & \multicolumn{3}{c}{ Implementation of creative character } \\
\cline { 2 - 4 } & $\mathrm{r}$ & Sig. & Interpretation \\
\hline Classroom & 0.330 & 0.000 & Low \\
School environment & 0.529 & 0.000 & Modest \\
Co-curriculum & 0.533 & 0.000 & Modest \\
\hline
\end{tabular}

Table 1 shows that there is a significant relationship between the level of students' acceptance with the implementation of NCE and creative characters in school. The strength of the relationship varies from low to modest $\quad(r=0.330$ to $r=$ 0.533). This shows that students' acceptance of the implementation of NCE has positive impacts on the implementation of creative characters.

\subsection{The contribution of students' acceptance of NCE to its implementation}

Structural Equation Model (SEM) analysis with AMOS 18.0 software was used to test how students' acceptance on the implementation of NCE in the class, school environment and during co-curricular activities would contribute to the level of students' self-esteem, reading habit, creative thinking and curiosity. Results of the SEM analysis are shown in Figure 4 below:

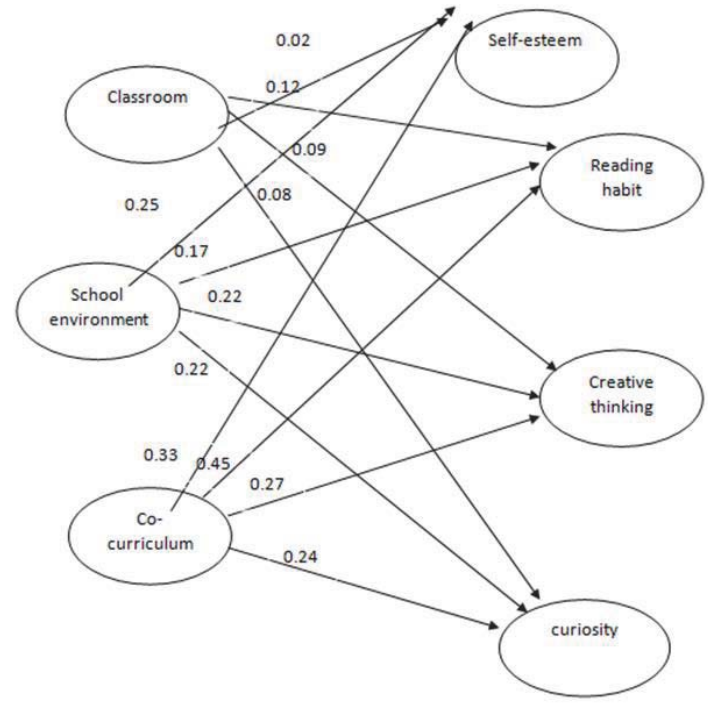

Figure 4. Hypothesis Model of students' acceptance and its contribution to the implementation of creative characters. 
SEM analysis using the AMOS 18 software shows that students' acceptance contributed to the implementation of creative characters. Results of the SEM analysis show the Chi Square/ $\mathrm{df}=12.410$, Root Mean Square Error Approximation $(\mathrm{RMSEA})=0.05$, Goodness of Fit Index $(\mathrm{GFI})=0.96$ and comparative fit index $(\mathrm{CFI})=0.93$. All measurements show that the data collected by this research has proven to be fit and compatible with the proposed model. The SEM result shows the regression model was compatible, as students' acceptance on the implementation in the classroom is a significant variables predictor to determine the other variables of reading habit $(\beta=0.12, p<0.05)$; creative thinking $(\beta=0.09, p<0.05)$ and curiosity $(\beta=0.08, p<0.05)$. Whereas classroom was not a predictor for selfesteem ( $\beta=0.02, p>0.05)$. However, students' acceptance on the implementation of Nation Character Education in the school environment was a significant predictor for the variables of self-esteem $(\beta=0.25, p<0.05)$; reading habit $(\beta=$ $0.17, p<0.05)$, creative thinking $(\beta=0.22, p<0.05)$ and curiosity $(\beta=0.22, p<0.05)$. In addition, students' acceptance on the implementation of Nation Character Education during co-curricular activities was a significant predictor for the variables of Self-esteem $(\beta=0.33, p<0.05)$; reading habit $(\beta=0.45, p<0.05)$, creative thinking $(\beta=0.27, p<0.05)$ and curiosity $(\beta=0.24, p<0.05$ ). This shows that students' acceptance of the implementation of NCE has significant contribution on the implementation of creative characters.

\section{Discussion}

Results of this study have found three significant levels of students' acceptance on how Nation Character Education was implemented in the school environment and during the school programs. The three levels of students' acceptance are : (1) High, (2) modest, and (3) Low. The aspects which received high acceptance are (1) the culture of smiling and greeting, (2) Implementation of stern school rules, (3) Execution of school events to inculcate positive values, and (4) Punctuality - the rule of early arrival at the school.

All of the four items are positively accepted and practised by students. The items are also accepted as a way of life. This shows that the schools have successfully implemented the education, which indirectly improved the schools' image among the wider community. Visitors who come to the schools would see the culture of smiling and greeting others being practised by all members of the schools, especially the students. According to Ab Aziz Yusof (2008), culture comprises of values, behaviours, beliefs, attitudes and customs uniformly practised by the whole community of an organization.

A culture of quality is naturally related to the elements of an organisation, in terms of works, technology, organisational structure, business strategies and financial decision making (Ehlers, 2009). According to Abdul Rahman, dkk (2008), a common practice of excellent culture would definitely increase the school's performance and indirectly would be benefited by all the parties involved.

Results of this study show that all students have agreed and accepted the 12 items of Nation Character Education implemented by teachers during the co-curricular activities. Students agreed that co-curricular activities made them closer with each other and promoted a sense of kinship among them. This finding is in agreement with Chin Pek Lian et al (2005) who admitted the importance of co-curricular activities in promoting cooperation and friendship among students, and at the same time they develop a strong individual personality. Students also gave positive responses on the impacts of co-curricular activities on their creativity. Co-curricular activities provide the opportunity for students to make their own decision to solve problem rationally. The activities are also complimenting formal learning session in the classroom, hence they increase students' creatitivity. Kingston International College in Australia has proven the benefits of cocurricular activities when it organised activities during the semester holidays. The activities allowed a continuous learning process even during the school break. Students learned about skills and were able to explore their own creativity when they participated in various fun and stress-free activities (Kingston International College, 2007).

This study has found poor students' acceptance on the implementation of Nation Character Education in the classroom, however their acceptance on the implementation in the school environment and during co-curricular activities is very modest. This is not surprising as naturally, students are more attracted to programs and activities which are fun, challenging and suitable to their interests. Classrooms are too formal for the young students, they would feel trapped and they would also very minimal chances for them to express their creativity and to appease their curiosity. On the other hand, open activities which are organised by the school such as campaigns, exhibitions and competitions would allow students to express their creativity and energy freely, without realizing that the teachers are actually inculcating positive values. This is in agreement with results of a research conducted by Niu, W., \& Sternberg. R.J. (2002) and Toh (2003), that the four aspects of creative characters (self-esteem, reading habits, creative thinking and curiosity) are best developed through organised and well-planned co-curricular activities. The programs and activities which are organised 
during the club meetings and games promote various skills and at the same time they increase the level of selfconfidence, skills for problem solving and decision making.

\subsection{Implications and recommendations}

Co-curricular activities contribute significantly to the development of students' characters. This is due to the fact that most of the activities require students to manipulate their own skills and at the same time promote positive values such as dedication, cooperation, and honesty. School environment is another more dominant factor to develop students' characters compared to classrooms. The implementation of character values in the classroom is found to be too formal and teachers' instruction is too rigid, make it impossible for students to digest the knowledge positively. Thus, informal condition in the school is deemed to be a more effective environment to implement character values. The semi-formal environment helps students to easily accept and practise the values. Hence, this is the natural way to develop one's personality. Due to that, it is necessary for the schools and administrators to create a school culture and environment by taking consideration of students' interests and needs.

Teachers need continuous exposure through in-service courses in order to improve their personality and diversify their knowledge. This is important for them to know how to provide affective situation while educating and inculcating characters values for the benefit of their students. Their ability to create a positive relationship with their students is another factor. A relation gap between a teacher and his students would weaken the teacher's credibility and at the same time makes it difficult to naturally inculcate values through role modeling. Teachers' initiatives to help students would mean a lot to their students. For example, they can simplify abstract terms using relevant examples and teaching aids.

Role modeling is another influential factor to develop students' attitudes. Teachers are their icons, hence every move taken by the teachers would be observed and copied by the students. Role modeling shows a concrete example, so it is important for teachers to carefully plan and execute their lessons in the simplest way possible for the students to easily accept and understand. According to Zahara Aziz et.al. (2009), reading habit or reading culture is still very poor among students and due to that it is not easy for them to understand several concepts. Hence, this is the main hurdle in the implementation and adaptation of values.

The number of respondents involved in this study is quiet small, hence the researcher would like to suggest for another future research using larger group of respondents. A larger group of respondents would represent more groups and promises a more valid result. In addition, future studies should involve other levels of schools at different areas of the whole Indonesia.

Apart from that, the Alternative Model used in this study could be used as a reference to develop better approach of nation character development. As it allows a more organise and comprehensive study with better constructs. The constructs for creative characters in the instrument can be described further by referring to multiple sources. This will help researchers to design a more comprehensive questionnaire to test various behaviours.

\subsection{Closing}

Social interaction provides chances for teachers to develop students' characters through trainings, practices and role modeling. Naturally, students learn and develop themselves through hidden curriculum of what they see, listen, feel and practise. However, the implementation of character values would differ from one school to another. It actually depends on the administrator' leadership styles and teachers' creativity. However, it is not easy to develop a culture, the acculturation process needs a long period of time until it becomes a common nature to members of the organisation. It also needs clear statements of rules and regulations. Apart from that, students also learn from mere observation, so it is important for the staff and teachers to show great examples, which in the long run would develop a new way of thinking and behaviours among the students.

\section{References}

Abdullah al-AMin al-Naimy. 1994. Kaedah dan Teknik Pengajaran Menurut Ibn Khaldun dan al-Qabisi (ed). Dewan Bahasa dan Pustaka: Kuala Lumpur.

Abdul-Rahman, H., Yahya, I.A., Berawi, M.A., \& Low, W.W. (2008). A conceptual model for mitigating delay in construction projects using a project learning approach, Construction Management and Economics, 26(1), pp15-27. (SCOPUS-Cited Publication).

Ab Aziz Yusof. 2008. Managing changes in the organization. Selangor. Arah Publications.

Ajat Sudrajat and Ari Wibowo, 2013. Developing good characters in the Muhammadiyah Condongcatur school, Universitas Negeri 
Yogyakarta.

Albertus, Doni Koesoema. (2007). Penilaian Pendidikan (Education Evaluation) in Menggugat Ujian Nasional. Memperbaiki Kualitas Pendidikan.

Biggs, J.(1987) Student approaches to learning and studying. Melbourne: Australian Council for Educational Research.

Booi-Chen Tan. 2011. The Role of Perceived Consumer Effectiveness on Value-Attitude-Behaviour Model in Green Buying Behaviour Context. Australian Journal of Basic and Applied Sciences, 5(12).

Character Education Partnership. 2000. National Schools of Character and Promising Practices. Washington, DC: Character Education Partnership.

Chin Pek Lian, Low Li Chuen and Vivian Low Yen Yeong, 2005. Discipline Problems among Students, Approaches and Salvation, . Skudai : UTM.

Conny Semiawan, dkk. (1984). Memupuk Bakat dan Kreativitas Siswa Sekolah Menengah. Jakarta: Gramedia.

Gede Raka (dkk). 2011. Character Education in schools from proposal to implementation.Jakarta: PT Gramedia Ibn Khaldun. 2002. The Muqaddimah. Bollingen series. Princeton University Press.

Indonesian Nation Character Development Blue Print, 2010. Ministry of Culture and Education, Republic of Indonesia

Kilpatrick, W. 1992. Why Johny can't tell right from wrong. New York: Simon \& Schuster. Inc.

Kingston International College, 2007. Perth, Western Australia.

Lickona, T. 1996. Eleven principles of effective charactereducation. Journal of Moral Education, 03057240, Mar96, Vol. 25, Issue 1

Niu, W., \& Sternberg. R.J. 2002. Contemporary studies on the concept of creativity: the East \& the West. Journal of Creative Behavior, $36(4), 269-288$

Ruyadi, Y. 2010. Model for local based character education. Proceedings of the $4^{\text {th }}$ International conferenvce on higher edication, Bandung : UPI \& UPSI, 8-10 November 2011

Seidman, I. 1998. Interviewing as qualitative research: a guide for research in education and the social science. $2^{\text {nd }}$ Ed. London: Teachers College Press.

Soemarno Soedarsono, H. 2010. Characters as the medium for a better future generation . Jakarta: Kompas Gramedia.

Sudrajat, Ajat. 2011. "Why character education?". Jurnal Pendidikan Karakter. Th I, No. 1, hlm. 47-58

Sumaatmadja, N. 2002. Humility education for human being. Bandung: Alfabeta

Taylor, S.J \& Bogdan, R. 1984. Introduction to qualitative research methods: The search of meaning. New York: A Wiley Interscience Publications.

The Curriculum Development Centre, Ministry of Education for the Republic of Indonesia (2010). Jakarta: Indonesia

Tilaar, H.A.R. 2007. Mengindonesia, etnisitas dan identitas bangsa Indonesia. Bandung: Rineka Cipta

Toh, W.S., 2003. Student - centered Educational Beliefs \&Teacher Education. Jurnal Penyelidikan MPBL, 4, 20-22.

Weisberg, R. W. 1999. Creativity and knowledge: A challenge to theories. In R. J. Sternberg (Ed.), Handbook of creativity (pp. 226-250). Cambridge: Cambridge University press.

Widodo, Tri dan Sri Kadarwati. 2013."Higher Order Thinking Berbasis Pemecahan Masalah untuk Meningkatkan Hasil Belajar Berorientasi Pembentukan Karakter Siswa". Cakrawala Pendidikan. Th. XXXII, No.1, hIm. 161-171.

Williams, M.M. 2000. Models of character education. Journal of Humanistic Counseling, Education and Development, 39(1), $32-40$.

Zahara Aziz, Abdul Razaq Ahmad dan Ahmad Rafaai Ayudin. 2009. Kepelbagaian sumber pengajaran untuk penerapan nilai dalam pembelajaran Sejarah (DIm) Abdul Razaq Ahmad \& Isjoni (pnyt.). Strategi dan Model Pembelajaran Sejarah. Pekanbaru: Cendekia Insani 
